\title{
Indicators' Dynamics of Irrigated Agriculture by Federal Districts of Russia
}

Alexandra Anatolyevna Ugryumova, Mikhail Petrovich Zamahovsky, Olgarenko Denis Gennadievich, Tatyana Alekseevna Kapustina

Federal State Research Institution All-Russia Scientific and Research Institute for Irrigation and Farming Water Supply Systems "Raduga”, Russia

\begin{abstract}
Currently, up to $80 \%$ of agricultural land needs watering in the Russian Federation. Therefore, the state of irrigated agriculture affects the efficiency and effectiveness of the country's food sector. The subject of this article is the studying of the basic indicators' dynamics of irrigated agriculture (total irrigated area, its condition: good, satisfactory and unsatisfactory, costs per hectare of irrigated area and actually watered area) and their interrelations in all federal districts of the Russian Federation for 2013-2016.
\end{abstract}

Methods of economic and statistical analysis were used in the work, in particular, analysis of the time series, correlation and cluster analyses.

As a result of the studying, it was established that the state and development of irrigated agriculture in the Russian Federation is unstable and cannot be regulated solely by climatic factors.

\section{Keywords}

Irrigated agriculture, irrigated area condition, cost per hectare of irrigated area, correlation analysis, cluster analysis.

Ugryumova, A. A., Zamahovsky, M. P., Gennadievich, O. D. and Kapustina T. A. (2019) “Indicators' Dynamics of Irrigated Agriculture by Federal Districts of Russia", AGRIS on-line Papers in Economics and Informatics, Vol. 11, No. 3, pp. 105-112. ISSN 1804-1930. DOI 10.7160/aol.2019.110310.

\section{Introduction}

One of the most important tasks of the subprogramme "Development of Land Reclamation for Agricultural Land of Russia for 2014-2020" is increasing the productive potential of irrigated land (Direction, 2013). Expansion of irrigated areas, improvement of their condition, improvement of irrigation technology and quality of management of irrigated areas increases productivity and reduces the payback period of funds invested in irrigated land use, contributes to increasing the competitiveness of irrigated areas (Jamin et al., 2011).

The studying over the long-term period of the development trends of irrigated agriculture and its economic and statistical analysis makes it possible to identify untapped development drivers, determine the points of economic growth of irrigated agriculture and increase its efficiency, which will allow not only meeting the needs of the population in agricultural production, but also increase the country's export capacity (Chernova and Gilina, 2009).
Compared with the other industrialised countries, the Russian Federation is located in an unfavorable climate zone for agriculture, which sharply reduces the competitiveness of agriculture, hinders the development of other sectors of the national economy, and causes an increased need for government support. In droughty, as well as in excessively wet years, the possibilities of highly productive varieties of crops, innovative technologies of their cultivation, and even progressive farming systems are not realised.

However, the territory of the Russian Federation is not homogeneous in terms of agricultural production and irrigated agriculture. It is necessary to distinguish regions that provide the maximum return on investment in irrigated land. Such territories as the SFD can be attributed as the most favorable from the point of view of natural climatic factors and ensuring the maximum effect from the investment in irrigated agriculture (Ugryumova, et al., 2018).

In all countries of the world with developed agriculture, the state allocates budget funds 
for the implementation of policies aimed at the rational using of water and other types of resources, through the modernisation and reconstruction of irrigation systems, the introduction of new environmentally friendly and resource-saving irrigation techniques, and optimisation of planning processes. (Klimova, 2013) The high costs of forming and expanding the fund of irrigated lands require not only careful monitoring, but also taking into account all factors affecting the optimal spending of funds. It is also necessary to counter government the destabilizing effects of the market environment.

The difficult situation in irrigated agriculture of the Russian Federation and the changing conditions of the socio-economic environment require detailed analysis, factors affecting the development and effectiveness of irrigated agricultural production. Allocation of the most characteristic and typical processes in irrigated agriculture of the country will allow the formation of specialised clusters of the Russian Federation's regions and work out unified methods of socioeconomic impact with respect to them, increasing their competitiveness (Alahtaeva, 2011).

The methods of statistical analysis make it possible to identify the causal interrelationships of the processes in irrigated agriculture, to determine the main trends of its development in the Russian regions and to analyse them taking into account all-Russian changes in the economy and legislation. These studies simultaneously make it possible to specify the prospects for the development of irrigation technology and technology, and, therefore, have an impact on the intensification of the development of agricultural production.

Similar surveys are carried out in other countries of the world using irrigated agriculture. So, for example, drip irrigation technologies are a serious area of research and development in one of the most agricultural-oriented countries in the world - India (Raut et al., 2014). In countries which are experiencing increased demand for water, particular importance is given to researching water reuse opportunities.

Glazyev argues that only 14 of the 85 subjects of the Russian Federation are net- food producers, and the remaining 71 act as net-consumers. This ratio reveals the special role of the regions that bear the main burden of the country's food supply. (Glazyev, 2016).

The aim of this article is the studying of the basic indicators' dynamics of irrigated agriculture (total irrigated area, its condition: good, satisfactory and unsatisfactory, costs per hectare of irrigated area and actually watered area) and their interrelations in all federal districts of the Russian Federation for 2013-2016.

\section{Materials and methods}

The authors of the article use materials from the Department of Land Reclamation of the Agriculture's Ministry of the Russian Federation, methods of economic and statistical analysis, in particular, the analysis of time series, correlation analysis, cluster analysis.

The authors conducted an economic and statistical analysis of the following basic indicators of irrigated agriculture:

$\mathrm{X}_{1}, \mathrm{X}_{2}, \mathrm{X}_{3}$ are the specific weights of irrigated lands, respectively, in good, satisfactory and unsatisfactory condition (\%);

$\mathrm{X}_{4}$ - the total cost per hectare of irrigated land (thousand rubles);

$\mathrm{X}_{5}$ - specific weights of actually watered areas $(\%)$;

$\mathrm{X}_{6}$ - the total area of irrigated land (thousand hectares)

by federal districts of Russia in 2013-2016 (Table 1).

In Table 2 the chain increments of these indicators for 2014-2016 are given.

From the Table 2 it follows:

- $\quad$ increasing of the total area of irrigated land with an increasing trend of costs per hectare of irrigated area was observed in the Central Federal District (2016), North Caucasian Federal District (2014), Volga Federal District (2014,2016), Siberian Federal District (2015), and with decreasing trend of expenses - in the Central Federal District (2014, 2015), the North-West Federal District (2014), the Southern Federal District (2016), the Ural Federal District (2016), the Volga Federal District (2015) and the Siberian Federal District (2014);

- decreasing of the proportion of areas in an unsatisfactory condition with an increasing trend of costs per hectare of irrigated area was observed in the SFD (2015), PFD (2016), FEFD (2015), and in a decreasing cost trend - in the CFA ( 2014-2015), the North-West Federal District (2014), the North Caucasian Federal District (2015), the Southern Federal 


\begin{tabular}{|c|c|c|c|c|c|c|c|}
\hline Year & Federal District & $\mathrm{X}_{1}, \%$ & $\mathrm{X}_{2}, \%$ & $X_{3}, \%$ & $\begin{array}{l}X_{4}, \text { thousand } \\
\text { roubles }\end{array}$ & $\mathrm{X}_{5}, \%$ & $\begin{array}{l}\mathrm{X}^{6}, \text { thousand } \\
\text { hectares }\end{array}$ \\
\hline \multirow{8}{*}{2013} & Central & 50.89 & 24.18 & 24.93 & 74.97 & 17.53 & 473.949 \\
\hline & Northwestern & 10.79 & 51.22 & 37.98 & 50.61 & 2.58 & 17.373 \\
\hline & North Caucasus & 46.67 & 23.74 & 29.59 & 32.31 & 44.79 & 925.506 \\
\hline & Southern & 57.27 & 20.47 & 22.26 & 51.46 & 53.53 & 1111.451 \\
\hline & Volga & 64.6 & 30.21 & 5.19 & 31.01 & 52.27 & 806.496 \\
\hline & Ural & 57.47 & 32.55 & 9.98 & 39.30 & 16.92 & 132.082 \\
\hline & Siberian & 50.36 & 39.19 & 10.45 & 47.56 & 47.42 & 498.605 \\
\hline & Far Eastern & 50.42 & 23.25 & 26.33 & 172.38 & 21.61 & 113.292 \\
\hline \multirow{8}{*}{2014} & Central & 51.18 & 24.08 & 24.73 & 40.05 & 17.54 & 480.054 \\
\hline & Northwestern & 7.21 & 58.37 & 34.42 & 45.86 & 4.39 & 17.660 \\
\hline & North Caucasus & 41.23 & 23.92 & 34.86 & 45.37 & 42.48 & 1023.165 \\
\hline & Southern & 57.80 & 20.19 & 22.01 & 36.01 & 38.97 & 1111.064 \\
\hline & Volga & 67.68 & 12.05 & 20.27 & 31.95 & 47.82 & 885.537 \\
\hline & Ural & 53.14 & 35.66 & 11.20 & 22.83 & 17.12 & 120.182 \\
\hline & Siberian & 50.80 & 40.63 & 8.57 & 16.65 & 47.20 & 499.801 \\
\hline & Far Eastern & 51.55 & 21.28 & 27.17 & 24.56 & 22.03 & 113.292 \\
\hline \multirow{8}{*}{2015} & Central & 52.37 & 23.77 & 23.86 & 31.10 & 13.57 & 482.568 \\
\hline & Northwestern & 7.59 & 56.69 & 35.72 & 40.19 & 2.84 & 16.772 \\
\hline & North Caucasus & 41.49 & 23.71 & 34.81 & 35.43 & 50.41 & 1017.944 \\
\hline & Southern & 57.00 & 21.43 & 21.57 & 62.94 & 33.77 & 1110.441 \\
\hline & Volga & 67.60 & 27.68 & 4.73 & 27.26 & 40.76 & 898.505 \\
\hline & Ural & 52.72 & 36.05 & 11.24 & 25.72 & 17.97 & 120.098 \\
\hline & Siberian & 49.46 & 41.53 & 9.01 & 83.29 & 38.56 & 499.807 \\
\hline & Far Eastern & 52.42 & 23.04 & 24.54 & 169.36 & 15.90 & 113.286 \\
\hline \multirow{8}{*}{2016} & Central & 43.63 & 30.80 & 25.58 & 52.65 & 12.09 & 484.900 \\
\hline & Northwestern & 7.59 & 54.90 & 37.51 & 47.57 & 0.00 & 16.772 \\
\hline & North Caucasus & 41.24 & 23.79 & 34.97 & 31.77 & 48.75 & 1013.949 \\
\hline & Southern & 57.61 & 20.82 & 21.56 & 40.64 & 34.28 & 1110.471 \\
\hline & Volga & 67.78 & 27.56 & 4.67 & 29.62 & 24.26 & 904.5247 \\
\hline & Ural & 52.78 & 35.97 & 11.26 & 21.18 & 17.39 & 120.508 \\
\hline & Siberian & 47.98 & 43.06 & 8.97 & 43.66 & 37.05 & 499.173 \\
\hline & Far Eastern & 47.30 & 23.23 & 29.47 & 36.13 & 17.47 & 113.286 \\
\hline
\end{tabular}

Source: compiled by the authors based on data from the Ministry of Agriculture of the Russian Federation

Table 1: Basic indicators of irrigated agriculture by federal districts of the Russian Federation for 2013-2016.

\begin{tabular}{|c|l|c|c|c|}
\hline \multirow{2}{*}{ Federal District } & \multicolumn{1}{|c|}{ Indicator } & \multicolumn{3}{|c|}{ Chain increments } \\
\cline { 2 - 5 } & & $\mathbf{2 0 1 4}$ & $\mathbf{2 0 1 5}$ & $\mathbf{2 0 1 6}$ \\
\hline \multirow{5}{*}{$\mathrm{CFD}$} & $\mathrm{X}_{1}, \%$ & 0.29 & 1.19 & -8.74 \\
\cline { 2 - 5 } & $\mathrm{X}_{2}, \%$ & -0.1 & -0.31 & 7.03 \\
\cline { 2 - 5 } & $\mathrm{X}_{3}, \%$ & -0.2 & -0.87 & 1.72 \\
\cline { 2 - 5 } & $\mathrm{X}_{4}$, thousand roubles & -34.92 & -8.95 & 21.55 \\
\cline { 2 - 5 } & $\mathrm{X}_{5}, \%$ & 0.01 & -3.97 & -1.48 \\
\cline { 2 - 5 } & $\mathrm{X}_{6}$, thousand hectares & 6.105 & 2.514 & 2.332 \\
\hline
\end{tabular}

Source: compiled by the authors based on data from the Ministry of Agriculture of the Russian Federation

Table 2: Chain increments of indicators $\mathrm{X}_{1}, \mathrm{X}_{2}, \mathrm{X}_{3}, \mathrm{X}_{4}, \mathrm{X}_{5}$ and $\mathrm{X}_{6}$ in the federal districts of the Russian Federation for 2014-2016 (to be continued). 


\begin{tabular}{|c|c|c|c|c|}
\hline \multirow{2}{*}{ Federal District } & \multirow{2}{*}{ Indicator } & \multicolumn{3}{|c|}{ Chain increments } \\
\hline & & 2014 & 2015 & 2016 \\
\hline \multirow{6}{*}{ NWFD } & $\mathrm{X}_{1}, \%$ & -3.58 & 0.38 & 0 \\
\hline & $\mathrm{X}_{2}, \%$ & 7.15 & -1.68 & -1.79 \\
\hline & $\mathrm{X}_{3}, \%$ & -3.56 & 1.3 & 1.79 \\
\hline & $\mathrm{X}_{4}$, thousand roubles & -4.75 & -5.67 & 7.38 \\
\hline & $\mathrm{X}_{5}, \%$ & 1.81 & -1.55 & -2.84 \\
\hline & $\mathrm{X}_{6}$, thousand hectares & 0.287 & -0.888 & 0 \\
\hline \multirow{6}{*}{ NCFD } & $\mathrm{X}_{1}, \%$ & -5.44 & 0.26 & -0.25 \\
\hline & $\mathrm{X}_{2}, \%$ & 0.18 & -0.21 & 0.08 \\
\hline & $\mathrm{X}_{3}, \%$ & 5.27 & -0.05 & 0.16 \\
\hline & $\mathrm{X}_{4}$, thousand roubles & 13.06 & -9.94 & -3.66 \\
\hline & $\mathrm{X}_{5}, \%$ & -2.31 & 7.93 & -1.66 \\
\hline & $\mathrm{X}_{6}$, thousand hectares & 97.659 & -5.221 & -3.995 \\
\hline \multirow{6}{*}{ SFD } & $\mathrm{X}_{1}, \%$ & 0.53 & -0.8 & 0.61 \\
\hline & $\mathrm{X}_{2}, \%$ & -0.28 & 1.24 & -0.61 \\
\hline & $\mathrm{X}_{3}, \%$ & -0.25 & -0.44 & -0.01 \\
\hline & $\mathrm{X}_{4}$, thousand roubles & -15.45 & 26.93 & -22.3 \\
\hline & $\mathrm{X}_{5}, \%$ & -14.56 & -5.2 & 0.51 \\
\hline & X6, thousand hectares & -0.387 & -0.623 & 0.03 \\
\hline \multirow{6}{*}{ PFD } & $\mathrm{X}_{1}, \%$ & 3.08 & -0.08 & 0.18 \\
\hline & $\mathrm{X}_{2}, \%$ & -18.16 & 15.63 & -0.12 \\
\hline & $\mathrm{X}_{3}, \%$ & 15.08 & -15.54 & -0.06 \\
\hline & $\mathrm{X}_{4}$, thousand roubles & 0.94 & -4.69 & 2.36 \\
\hline & $\mathrm{X}_{5}, \%$ & -4.45 & -7.06 & -16.5 \\
\hline & $\mathrm{X}_{6}$, thousand hectares & 79.041 & 12.968 & 6.0197 \\
\hline \multirow{6}{*}{ UFD } & $\mathrm{X}_{1}, \%$ & -4.33 & -0.42 & 0.06 \\
\hline & $\mathrm{X}_{2}, \%$ & 3.11 & 0.39 & -0.08 \\
\hline & $\mathrm{X}_{3}, \%$ & 1.22 & 0.04 & 0.02 \\
\hline & $\mathrm{X}_{4}$, thousand roubles & -16.47 & 2.89 & -4.54 \\
\hline & $\mathrm{X}_{5}, \%$ & 0.2 & 0.85 & -0.58 \\
\hline & $\mathrm{X}_{6}$, thousand hectares & -11.9 & -0.084 & 0.41 \\
\hline \multirow{6}{*}{ SFD } & $\mathrm{X}_{1}, \%$ & 0.44 & -1.34 & -1.48 \\
\hline & $\mathrm{X}_{2}, \%$ & 1.44 & 0.9 & 1.53 \\
\hline & $\mathrm{X}_{3}, \%$ & -1.88 & 0.44 & -0.04 \\
\hline & $\mathrm{X}_{4}$, thousand roubles & -30.91 & 66.64 & -39.63 \\
\hline & $\mathrm{X}_{5}, \%$ & -0.22 & -8.64 & -1.51 \\
\hline & $\mathrm{X}_{6}$, thousand hectares & 1.196 & 0.006 & -0.634 \\
\hline \multirow{6}{*}{ FEFD } & $\mathrm{X}_{1}, \%$ & 1.13 & 0.87 & -5.12 \\
\hline & $\mathrm{X}_{2}, \%$ & -1.97 & 1.76 & 0.19 \\
\hline & $\mathrm{X}_{3}, \%$ & 0.84 & & 4.93 \\
\hline & $\mathrm{X}_{4}$, thousand roubles & -147.82 & 144.8 & -133.23 \\
\hline & $\mathrm{X}_{5}, \%$ & 0.42 & -6.13 & 1.57 \\
\hline & $\mathrm{X}_{6}$, thousand hectares & 0 & -0.006 & 0 \\
\hline
\end{tabular}

Source: compiled by the authors based on data from the Ministry of Agriculture of the Russian Federation

Table 2: Chain increments of indicators $\mathrm{X}_{1}, \mathrm{X}_{2}, \mathrm{X}_{3}, \mathrm{X}_{4}, \mathrm{X}_{5}$ and $\mathrm{X}_{6}$ in the federal districts of the Russian Federation for 2014-2016 (continuation). 
District $(2014,2016)$, the Volga Federal District (2015), and the Siberian Federal District (2014, 2016);

- increasing of the proportion of actually watered areas with an increasing trend of costs per hectare of irrigated area was observed in the UFO (2015), and with a decreasing trend in costs - in the Central Federal District (2014), North-West Federal District (2014), North-Caucasian Federal District (2015), South Federal District (2016), UFO (2014) and the Far Eastern Federal District (2014, 2016).

- Considering that the proportion of actually watered areas also depends on climatic conditions, the dynamics of irrigated agriculture can be considered positive if the total area of irrigated land increases and the proportion of areas in an unsatisfactory condition decreases. Thus, the positive dynamics of irrigated agriculture in 2014 was observed in the Central Federal District, NorthWestern Federal District and Siberian Federal District, in 2015 - in the Central Federal District and Volga Federal District, and in 2016 - in the Southern Federal District and Volga Federal District.

- The Table 3 shows the linear coefficients of pair correlation of costs per 1 hectare of irrigated areas and the rest of the analyzed factors by federal districts. At the same time, a positive coefficient indicates a direct relationship (with an increase in the values of one indicator, the values of the other increase), and a negative coefficient indicates an inverse relationship (with an increase in the values of one indicator, the values of the other increase).
The analysis (Table 3) leads to the following conclusions:

- the dependence of the proportion of areas in good condition on the cost of 1 ha direct in the Northwestern Federal District, UFD and Far Eastern Federal District, in other districts it is inverse, while it is strong in the SFD and UFD, noticeable in the NWFD, moderate in the PFD, SFD and DFD, weak in CFD;

- the dependence of the proportion of areas in satisfactory condition on the cost of 1 ha direct in the Central Federal District, NorthCaucasian Federal District, Southern Federal District, North-Eastern Federal District and Far Eastern Federal District, in other districts it is reverse, while it is strong in North-West Federal District, Southern Federal District and Volga Federal District, noticeable in the North-Western Federal District, Volga Federal District and FarEastern Federal District, weak in the Central Federal District and Siberian Federal District;

- the dependence of the proportion of areas in an unsatisfactory condition on the cost per 1 ha direct in the Central Federal District, North-West Federal District, North Caucasus Federal District, Volga Federal District and Siberian Federal District, in other districts it is reverse, while it is strong in the Volga Federal District and Far Eastern Federal District, moderate in the Volga Federal District, North Caucasus Federal District, moderate North Volga Federal District and weak in the SFD and SFD;

- the dependence of the proportion of actually watered areas on the cost of 1 ha is direct in the Central Federal District, Southern Federal District and Volga Federal District, it is reversed in other districts, while it is noticeable in the SCF and SFD, moderate in the Central Federal District, Volga Federal

\begin{tabular}{|c|c|c|c|c|c|c|c|c|}
\hline Factor & \multicolumn{9}{|c|}{ Federal districts } \\
\hline & CFD & NWFD & NCFD & SFD & PFD & UFD & SFD & FEFD \\
\hline $\mathrm{X}_{1}$ & -0.23 & 0.67 & -0.42 & -0.99 & -0.32 & 0.97 & -0.35 & 0.46 \\
\hline $\mathrm{X}_{2}$ & 0.15 & -0.69 & 0.82 & 0.80 & -0.56 & -0.96 & 0.17 & 0.59 \\
\hline $\mathrm{X}_{3}$ & 0.59 & 0.61 & 0.4 & -0.21 & 0.67 & -0.97 & 0.2 & -0.78 \\
\hline $\mathrm{X}_{5}$ & 0.36 & -0.24 & -0.63 & 0.03 & 0.43 & -0.47 & -0.56 & -0.17 \\
\hline $\mathrm{X}_{6}$ & -0.69 & 0.44 & 0.48 & -0.22 & -0.45 & 0.97 & 0.07 & -0.03 \\
\hline
\end{tabular}

Source: compiled by the authors based on data from the Ministry of Agriculture of the Russian Federation

Table 3: Linear correlation coefficients of costs per 1 ha of irrigated area and analysed factors. 
District, Volga Federal District, is weak in the SFD;

- the dependence of the total irrigated area on the cost per 1 ha is direct in the Northwestern Federal District, North Caucasus Federal District, UFD and SFD, in other districts it is reverse, while it is strong in UFD, noticeable in the Central Federal District, moderate in the Northwest Federal District, North Caucasian Federal District, Volga Federal District, weak in the Southern Federal District and is absent in the SFD and FEFD.

As a result of the cluster analysis performed by the k-means method in the SPSS statistical package on the basis of the state indicators for 2013-2016, three clusters of federal districts were formed, the cluster profiles of which (average values of indicators in federal districts located in one cluster) are given in (Table 4).

\section{Results and discussion}

First of all the conducted cluster analysis confirmed the steady position of the federal districts in the four-year retrospective analysis, which testifies to the well-established positioning of these territories in irrigated agriculture.

These findings are fully correlated with previous studies conducted and published by the authors, devoted to the analysis of the using of irrigated land in the Federal Districts of the Russian Federation (Ugryumova et al., 2018).

Analysis (Table 4) showed that during the studying period from 2013 to 2016 the federal districts of the 1st cluster (North Caucasus Federal District, the Southern Federal District and the Volga Federal District) occupied the first places, the districts of the $2^{\text {nd }}$ cluster (the Central Federal District and the Siberian Federal District) ranked second, and the districts of the $3^{\text {rd }}$ cluster (the NorthWest Federal District, the Volga Federal District and the Far Eastern Federal District) occupied third position in irrigated agriculture. It should be noted that all districts with positive dynamics of irrigated areas, except for the North-West Federal District, were included in the $1^{\text {st }}$ and $2^{\text {nd }}$ clusters.

\begin{tabular}{|c|c|c|c|c|c|c|c|}
\hline \multirow[b]{3}{*}{2013} & \multicolumn{3}{|c|}{ Clusters } & \multirow[b]{3}{*}{2014} & \multicolumn{3}{|c|}{ Clusters } \\
\hline & 1 & 2 & 3 & & 1 & 2 & 3 \\
\hline & $\begin{array}{c}\text { NCFD } \\
\text { SFD } \\
\text { PFD }\end{array}$ & $\begin{array}{l}\text { CFD } \\
\text { SFD }\end{array}$ & $\begin{array}{c}\text { NWFD } \\
\text { UFD } \\
\text { FEFD }\end{array}$ & & $\begin{array}{c}\text { NCFD } \\
\text { SFD } \\
\text { PFD }\end{array}$ & $\begin{array}{l}\text { CFD } \\
\text { SFD }\end{array}$ & $\begin{array}{c}\text { NWFD } \\
\text { UFD } \\
\text { FEFD }\end{array}$ \\
\hline \multicolumn{8}{|c|}{ Cluster Profiles } \\
\hline Indicators & \multicolumn{3}{|c|}{ Average values } & Indicators & \multicolumn{3}{|c|}{ Average values } \\
\hline$X_{1}$ & 56.18 & 50.63 & 39.56 & $\mathrm{X}_{1}$ & 55.57 & 50.99 & 37.30 \\
\hline$X_{2}$ & 24.81 & 31.69 & 35.67 & $X_{2}$ & 18.72 & 32.36 & 38.44 \\
\hline $\mathrm{X}_{3}$ & 19.I & 17.69 & 24.76 & $X_{3}$ & 25.71 & 16.65 & 24.26 \\
\hline$X_{4}$ & 38.26 & 61.27 & 87.43 & $X_{4}$ & 37.78 & 28.35 & 31.08 \\
\hline$X_{5}$ & 50.20 & 32.48 & 13.70 & $X_{5}$ & 43.09 & 32.37 & 14.51 \\
\hline$X_{6}$ & 947.82 & 486.28 & 87.58 & $X_{6}$ & 1006.59 & 489.93 & 83.71 \\
\hline \multirow{3}{*}{2015} & \multicolumn{3}{|c|}{ Clusters } & \multirow{3}{*}{2016} & \multicolumn{3}{|c|}{ Clusters } \\
\hline & 1 & 2 & 3 & & 1 & 2 & 3 \\
\hline & $\begin{array}{c}\text { NCFD } \\
\text { SFD } \\
\text { PFD }\end{array}$ & $\begin{array}{l}\text { CFD } \\
\text { SFD }\end{array}$ & $\begin{array}{l}\text { NWFD } \\
\text { UFD } \\
\text { FEFD }\end{array}$ & & $\begin{array}{c}\text { NCFD } \\
\text { SFD } \\
\text { PFD }\end{array}$ & $\begin{array}{l}\text { CFD } \\
\text { SFD }\end{array}$ & $\begin{array}{l}\text { NWFD } \\
\text { UFD } \\
\text { FEFD }\end{array}$ \\
\hline \multicolumn{8}{|c|}{ Cluster Profiles } \\
\hline Indicators & \multicolumn{3}{|c|}{ Average values } & Indicators & \multicolumn{3}{|c|}{ Average values } \\
\hline $\mathrm{X}_{1}$ & 55.36 & 50.92 & 37.58 & $\mathrm{X}_{1}$ & 55.54 & 45.81 & 35.89 \\
\hline $\mathrm{X}_{2}$ & 24.27 & 32.65 & 38.59 & $X_{2}$ & 24.VI & 36.93 & 38.03 \\
\hline $\mathrm{X}_{3}$ & 20.37 & 16.44 & 23.83 & $X_{3}$ & 20.40 & 17.28 & 26.VIII \\
\hline $\mathrm{X}_{4}$ & 41.88 & 57.20 & 78.42 & $\mathrm{X}_{4}$ & 34.01 & 48.16 & 34.96 \\
\hline $\mathrm{X}_{5}$ & 41.65 & 26.VII & XII.24 & $\mathrm{X}_{5}$ & 35.76 & 24.57 & XI.62 \\
\hline$X_{6}$ & 1008.96 & 491.19 & 83.39 & $X_{6}$ & 1009.65 & 492.04 & 83.52 \\
\hline
\end{tabular}

Source: compiled by the authors based on data from the Ministry of Agriculture of the Russian Federation

Table 4: Federal District Clusters and their Cluster Profiles. 


\section{Conclusion}

The state and development of irrigated agriculture in the Russian Federation is unstable and cannot be regulated solely by climatic factors (in particular, the quality of federal and regional government, the size and structure of financial flows, etc.) affect the development of irrigated agriculture. Strong enough on the development of irrigated agriculture is influenced by the material and technical condition of the existing equipment and its level of wear ${ }^{1}$.

The cost per hectare of irrigated area across federal districts is highly differentiated and is not

\footnotetext{
${ }^{1}$ Ugryumova, A. A., Zamakhovsky, M P, Kapustina, T. A. (2018)
"Technological safety of agriculture in regions with land reclamation

${ }^{1}$ Ugryumova, A. A., Zamakhovsky, M P, Kapustina, T. A. (2018)
"Technological safety of agriculture in regions with land reclamation agriculture", National interests: priorities and security, Vol. 14, No. 2, pp. 221 - 235.
}

\section{Corresponding authors}

Alexandra Ugryumova, doctor of economics, professor

Plekhanov Russian University of Economics, Stremyanny lane, 36, Moscow, 117997, Russia

Phone:+7(915)501-63-10, Email:feminaa@mail.ru

always effective regardless of the area's climatic conditions.

Throughout 2013-2016 the North Caucasus Federal District, the Southern Federal District and the Volga Federal District were the leaders, and the Northwestern Federal District, the Ural Federal District and the Far Eastern Federal District were outsiders in irrigated agriculture.

It is necessary to improve the existing and develop new methodological approaches to managing the economic development of irrigated agriculture, justifying federal and regional funding for irrigated agriculture, and developing proposals for improving the efficiency of investment in irrigated agriculture of private land users of the Russian Federation.

\section{References}

[1] Alahtaeva, N.M. (2011) "Justification of the cluster policy in order to develop agricultural production in the regions", Herald of the Krasnodar State Agrarian University, No. 10. [Online]. Available: https://cyberleninka.ru/article/v/obosnovanie-provedeniya-klasternoy-politiki-s-tselyu-razvitiyaselskohozyaystvennogo-proizvodstva-v-regionah [Accessed: 16 Jan. 2019].

[2] Glazyev, S.Y. (2016) "О продовольственной безопасности России" (in Russian), Report of the group of experts of the Izborsky Club under the leadership of Academician of RAS S. Y. Glazyev. [Online]. Available: http://www.dynacon.ru/content/articles/1725. [Accessed: 15 Jan. 2019].

[3] Jamin, J.-Y., Bouarfa, S., Poussin, J.-C. and Garin, P. (2011) "Irrigated agriculture facing new challenges", Cahiers Agricultures, Vol. 20, No. 1-2, pp. 10-15. ISSN 1166-7699. DOI 10.1684/agr.2011.0477.

[4] Klimova, N. V. (2013) "Features of the regulatory impact of the state on agribusiness in foreign countries", Scientific journal KubGAU, No. 90 (06). [Online]. Available: https://cyberleninka.ru/ article/v/osobennosti-reguliruyuschego-vozdeystviya-gosudarstva-na-agrobiznes-v-zarubezhnyhstranah [Accessed: 25 Jan. 2019].

[5] Direction (subprogram) (2019) "Development of Land Reclamation for Agricultural Lands of Russia for 2014-2020" (approved by the Decree of the Government of the Russian Federation by October 12, 2013 N 922). [Online]. Available: http://ivo.garant.ru/\#/document/70210644/paragraph/5468590:2 [Accessed: 1 Feb. 2019].

[6] Raut, S. M., Agarwal, P. K., Singh, O. P. (2014) "Economic viability of drip irrigation in cotton in Jalna district of Maharashtra, India", Annals of Agri Bio Research, Vol. 19, No. 2, pp. 316-320. ISSN 0971-9660.

Ugryumova, A. A., Zamakhovsky, M. P., Pautova, L. E., Tyurina, L. M. (2018) "Analysis of the potential's using of irrigated agriculture on the example of the Southern Federal District", Regional Economics: Theory and Practice, Vol. 16, No. 11 (458), pp. 2075-2091. E-ISSN 2311-8733, ISSN ISSN 2073-1477. DOI 10.24891/re.16.11.2075. 
[7] Ugryumova, A. A., Olgarenko, D. G., Zamakhovsky, M. P. (2018) "The analysis of the main factors of the irrigated agriculture in the federal districts of the Russian Federation", International Multidisciplinary Scientific GeoConference SGEM, Vol. 18, No. 5.3, pp. 831-838. ISBN 978-619-7408-48-5. ISSN 1314-2704. DOI 10.5593/sgem2018/5.3/S28.106.

[8] Chernova, T. V., Gilina, T. G. (2009) "Economic-statistical study of factors affecting the regional productivity of agricultural production", Regional Economics: Theory and Practice, Vol. 11, No. 104, pp. 62-67. [Online]. Available: https:/cyberleninka.ru/article/v/ekonomiko-statisticheskoeizuchenie-faktorov-vliyayuschih-na-regionalnuyu-proizvoditelnost-selskohozyaystvennogoproizvodstva [Accessed: 30 Jan. 2019]. 